Kornelija Ajlec

\title{
Ben Shepard: The Long Road Home: The Aftermath of the Second World War
}

London: The Bodley Head, 2010, 489 strani

Velika Britanija je še trepetala pred morebitno nemško invazijo, ko je Winston Churchill 20. avgusta 1940 izrekel presenetljivo zaobljubo, da bodo po padcu nacističnega režima zmagovalci priskrbeli hrano in svobodo državam, ki jih je zasužnjil Hitler. Tudi Nemčiji in Avstriji. Agencijo združenih narodov za pomoč in obnovo UNRRA so ustanovili tri leta kasneje. Konec druge svetovne vojne ni prinesel miru čez noč, ampak je bil to nemiren in nemalokrat smrtonosen čas. Kot je resnica za Oscarja Wilda le redko nedolžna in nikoli preprosta, tudi zmaga ob koncu druge svetovne vojne ni bila zgolj uvod v celjenje ran in obnovo porušenega sveta.

Zaradi vojne je več milijonov civilistov zapustilo domovino, hkrati pa je bila osvoboditev tudi povod za novo nasilje v vzhodni Evropi, iz katere so ena za drugo odhajale železniške kompozicije s številnimi izgnanci nemškega porekla, ki so jim rekli Volksdeutscherji. Tudi mnogi preživeli poljski Židje so pobegnili pred novim valom preganjanja. Zbežali so v zavezniške cone v Nemčiji in Avstriji, kjer so dovolj srečni dobili status razseljene osebe, s katerim so bili upravičeni do hrane in prenočišča.

Ocenjujejo, da je bilo treba po vojni rehabilitirati osem milijonov beguncev. To nalogo je prevzela UNRRA, ki je priskrbela hrano, zdravila in drugo humanitarno pomoč v vrednosti štirih milijard takratnih dolarjev. Ben Shephard v knjigi Dolga pot domov: Učinek druge svetovne vojne piše, da se niti UNRRA niti vojaške oblasti niso znale spopasti z milijoni beguncev, ki so preplavili mesta, kot sta Heidelberg in Frankfurt. Medtem ko so umori, posilstva in ropi postali del vsakdana, je humanitarno organizacijo hromil predvsem zapleten birokratski aparat, ki mu je kljub visokim plačam kronično primanjkovalo ustreznega osebja. Za povrh so se nekateri uslužbenci radi ukvarjali s preprodajo zalog na črnem trgu ali pa s pomočjo pri nezakoniti imigraciji Židov v Palestino. Med slednjimi je bil celo drugi direktor agencije Fiorello LaGuardia.

Zavezniki se s humanitarno pomočjo seveda niso ukvarjali zgolj iz človekoljubnih razlogov. Herbert Lehman, prvi direktor UNRRE, je na primer izjavil, da »hoče videti preklete fašiste moledovati Žida za hrano«. Še najbolj so se bali lakote in izbruha nalezljivih bolezni, ki bi ji sledil, saj je bil spomin na morijo španske gripe po prvi 
svetovni vojni še kako živ. Hkrati se je $\mathrm{z}$ začetkom hladne vojne okrepil pomen zdrave in močne Evrope, ki naj bi služila kot utrdba pred širitvijo komunizma. Tako niti ni čudno, da je tedaj krožila šaljiva razlaga kratice UNRRA »You never really rehabilitate anyone« oziroma »Nikoli nikogar niste zares rehabilitirali«.

Kljub temu je UNRRI delna rehabilitacija le uspela. Njena glavna naloga je bila namreč vračanje večine razseljenih oseb v domovino, kar je tudi izpeljala - včasih celo na silo, kot v primeru nekaterih beguncev iz Ukrajine in Jugoslavije, ki so jih upravičeno ali pa tudi ne obtožili sodelovanja z okupatorjem. Ti so se zavedali, da bodo postali predmet novih nasilnih ukrepov in osebje v taboriščih je bilo zgroženo, ko so nekateri Ukrajinci raje drug drugemu pregriznili vratno žilo, kot da bi se vrnili v domovino. Res je bilo veliko beguncev tudi zares kolaboracionistov, a presenetljivo so prav ti mnogokrat dobili nov dom v zahodnih državah prej kot številni Židje in drugi politični begunci, saj so bili po mnenju marsikoga rasno »čistejši«. Po vojni je Angleško socialistično društvo (Fabian Society) poudarjalo potrebo po sprejemu delavcev "primernega porekla «, saj se »evgenika emigracije ne more dovolj poudariti«. Tudi v Združenih državah Amerike so raje sprejemali državljane baltskih držav kot Žide.

V taboriščih UNRRE je ostal še približno poldrugi milijon beguncev, ki se niso želeli ali mogli vrniti v domovino. Številnim zavzetim delavcem agencije je tem beguncem uspelo zagotoviti življenjski standard, ki so jim ga zavidali drugi prebivalci gospodarsko šibke Nemčije, in tako UNRRI ustvarili današnji ugled. Kasneje so odkrili tri primere, ko so se Nemci spreobrnili v židovsko vero in se dali obrezati samo zato, da bi dobili obrok hrane, ki je pripadal beguncem. Kljub precejšnjem številu Židov delavcem UNRRE ni bilo vselej jasno, kaj se je pravzaprav dogajalo z njimi med drugo svetovno vojno. Njihovo delo je bilo omejeno na množice prizadetih posameznikov, ki jih birokrati povečini niso mogli razumeti. Odrasli so vedno znova podoživljali grozote koncentracijskih taborišč, otroke, evakuirane iz koncentracijskega taborišča Buchenwald, pa so imeli za "nedisciplinirane, neuravnovešene, primitivne in celo živalske». Čeprav so bili Židje neenotni, so jih izkušnje iz nacističnih taborišč prisilile v vsaj navidezno enotnost, $\mathrm{v}$ kateri so stremeli k čim večji avtonomiji znotraj begunskih taborišč. Te so vodili skoraj po vojaških načelih, celo $\mathrm{z}$ uniformami, zastavami in propagando.

Takšne in še številne druge zapletene zgodbe je avtor raziskal vestno in podrobno. Kot vir je uporabil dnevnike, pisma, spomine, govore, intervjuje ter arhivske dokumente vladnih in nevladnih organizacij, s katerimi je poustvaril zgodovino začasne oskrbe, repatriacij in naselitve razseljenih oseb, večinoma na ozemlju Nemčije. Tako je odlično povezal doživetja vidnejših vojaških in političnih oseb ter številnih beguncev $\mathrm{v}$ taboriščih, katerih zapise in izjave je spretno vpletel v svojo knjigo. Pohvalno je, da je avtor že v uvodu izpostavil številne ovire, ki jih je treba upoštevati pri proučevanju 
zgodovine beguncev po drugi svetovni vojni. Izpostavil je, da so številni dokumenti vladnih in nevladnih agencij togi in da zanemarjajo osebne izkušnje razseljenih oseb. Tudi odnos zaveznikov do beguncev se je spreminjal hkrati s političnim položajem in začetkom hladne vojne. Vsak zgodovinar, ki se ukvarja s to tematiko, mora biti dobro poučen o sodobni zgodovini vseh držav in narodov, ki se jih ta problematika dotika. Ta se namreč neposredno navezuje na splošno, begunsko in emigracijsko politiko vpletenih držav po drugi svetovni vojni.

Kljub vsem tem pastem je avtor ustvaril lahko berljivo in podatkov polno študijo. Nasploh je knjiga napisana tako, da nekatere pomanjkljivosti z lahkoto prezremo. Večina avtorjevih virov je britanskih, kar seveda ponuja izrazito britansko perspektivo dogajanja, ki se kaže pri nekoliko pristranski predstavitvi nesoglasij z ameriškimi uradniki. Nekoliko sporna je morda tudi dokaj pavšalna uporaba sekundarnih virov, med njimi najdemo na primer Petra Novicka, ki trdi, da je koncept holokavsta kasnejša konstrukcija ameriških Židov v iskanju zgodovinske in politične identitete. Prav tako avtor izpostavi en sam citat iz dnevnika ameriškega predsednika Harryja Trumana o sebičnosti Židov in ga posledično označi za antisemita, čeprav je Truman zelo podpiral ustanovitev izraelske države.

$\mathrm{Na}$ splošno lahko trdimo, da se avtor ne ukvarja veliko $\mathrm{z}$ nacističnimi kolaboracionisti in s tem, kako so se skrivali v zahodnih državah. To je ob dejstvu, da se je ameriško zgodovinopisje nekaj let po odprtju nekaterih arhivskih dokumentov začelo aktivneje ukvarjati s to tematiko, nenavadno. Prav tako se avtor pretirano ne posveča pozitivnim in negativnim stranem delovanja Rdečega križa in Mednarodne službe za iskanje pogrešanih.

Avtor pa je po drugi strani odlično povezal težave razseljenih oseb s težavami zavezniške uprave v Nemčiji, še posebej odnos med Nemci v Nemčiji in Volksdeutscherji, ki jih zavezniki niso šteli med razseljene osebe. Prav tako zelo dobro prikaže britansko nasprotovanje in ameriško podporo preseljevanju Židov v Palestino, še posebej po predlaganem kompromisu angloameriškega komiteja, ki je predlagal razdelitev Palestine na židovski in arabski del ter dovolil emigracijo 150 tisoč Židov. Britanci so kompromis zavrnili, kar jih je nazadnje stalo mandata v Palestini.

Do leta 1951 se več kot milijon razseljenih oseb ni vrnilo domov. Kljub temu, da so jih medvojne in povojne izkušnje neizbrisno zaznamovale, si je večina beguncev v novi domovini ustvarila drugo življenje in mnogi so postali pomemben steber lokalne družbe. Zadnji del knjige je posvečen osebnim zgodbam, ki pričajo o novem življenju posameznikov in njihovih potomcev. S tem knjiga dobi drugačno dimenzijo, ki je pri opisovanju te tematike ne najdemo pogosto. 